\title{
Is mitochondrial antibody diagnostic of primary biliary cirrhosis?
}

\author{
LINDA E MUNOZ, H C THOMAS,* P J SCHEUER, DEBORAH DONIACH, \\ AND SHEILA SHERLOCK \\ From the Department of Medicine and Histopathology, Royal Free Hospital, London, and the \\ Department of Immunology, Middlesex Hospital Medical School, London
}

SUMMARY In a series of 218 patients diagnosed as having primary bilary cirrhosis only nine exhibited a negative serum mitochondrial antibody. On examining additional specimens from thesepatients, seven were found to be positive, giving a final incidence of greater than $99 \%$. The two. patients whose sera remained negative for the mitochondrial antibody had liver histology com-. patible with the diagnosis of primary biliary cirrhosis, but a firm diagnosis could not be reached. Three additional mitochondrial antibody positive subjects who were asymptomatic and exhibited normal serum alkaline phosphatase were shown on liver biopsy to have stage I primary biliary cirrhosis. The presence of a positive serum mitochondrial antibody in a patient with or without. abnormalities in liver function tests strongly suggests the diagnosis of primary biliary cirrhosis.

Primary biliary cirrhosis is a disease of unknown aetiology in which the epithelium of the intrahepatic biliary tree is destroyed by a chronic inflammatory process characterised by the presence of granulomata.

The incidence of mitochondrial antibody in patients diagnosed on the basis of a suggestive clinical history, cholestatic liver function tests, raised serum IgM, and a compatible histological appearance has varied from 83 to $98 \% .^{1-6}$ When primary biliary cirrhosis was diagnosed at the presymptomatic stage, mitochondrial antibody was present in 90 to $100 \%$ of cases. ${ }^{78}$

To investigate further the specificity of the relationship of the mitochondrial antibody to primary biliary cirrhosis, we have tested a large group of patients who, on clinical, biochemical, and histological grounds, have this disease. We have also examined three apparently normal subjects who were mitochondrial antibody positive, for the presence of liver disease.

\section{Methods}

PATIENTS

A review of the clinical and liver biopsy material from January 1973 to December 1977 at the Royal

*Address for correspondence and reprint requests: H C Thomas, Department of Medicine, Royal Free Hospital, Pond Street. London NW3 2QG, United Kingdom.

Received for publication 18 August 1980
Free Hospital identified 218 patients with the diagnosis of primary biliary cirrhosis. In nine patients mitochondrial antibody was negative at presentation, the diagnosis being made on the basis of symptoms, biochemistry, and liver histology. Additional specimens from these patients were examined for the presence of mitochondrial antibody. The original specimens were not available for retesting and in general the repeat specimen was obtained within one to five years.

Three additional subjects were included in the study. All were mitochondrial antibody positive with normal alkaline phosphatase and IgM. These patients were studied clinically, biochemically, serologically, and histologically for stigmata of primary biliary cirrhosis.

\section{SEROLOGY}

Mitochondrial, smooth muscle, nuclear, and thyroid autoantibodies were done in two laboratories (Royal Free Hospital and Middlesex Hospital). Mitochondrial, smooth muscle, and nuclear autoantibodies were detected by indirect immunofluorescence. Rat kidney, stomach, and liver were used as substrate at the Royal Free Hospital. At the Middlesex Hospital human thyroid, submaxillary gland, and kidney, as well as rat liver and kidney, were used as substrate. Cryostat sections were made. After drying the slide at room temperature for one hour, the tissue: was covered with 1/10 (Royal Free Hospital) and. 
undiluted sera as well as $1 / 10$ (Middlesex Hospital) for screening. Positive samples were titrated. After 30 minutes at room temperature, the slides were washed twice in Coons buffer for five minutes, fixed in absolute alcohol for three minutes, rinsed in Coons buffer, and then FITC antibody was added and left for $\mathbf{3 0}$ minutes. Duplicate unfixed slides were tested. Positive and negative controls were used.

Two patients who remained negative for mitochondrial antibody on retesting by immunofluorescence were also tested by complement fixation (ICF) using anti-C3 conjugate.

Thyroid (thyroglobulin and microsomal) autoantibodies were detected by a haemagglutination test using sheep red cells coated with human thyroid antigens (Wellcome Laboratories and Fujizoki Pharmaceutical Co Ltd).

\section{HISTOLOGICAL EXAMINATION}

Liver biopsies were processed and stained by routine method. The rhodanine stain was used to demonstrate copper, and the orcein stain for copperassociated protein. Both were semi-quantitatively graded from 0 to ++++ . Indirect immunoperoxidase testing for alpha 1 antitrypsin was carried out.

\section{Results}

\section{MITOCHONDRIAL ANTIBODY NEGATIVE}

PRIMARY BILIARY CIRRHOSIS

On retesting additional serum specimens (obtained 12 to 60 months after the first specimen) from the nine mitochondrial antibody negative patients, five patients were found to be positive at the Royal Free Hospital (patients 5-9) (Table 1). These patients were
Table 1 Autoantibody titres

\section{Case Substrate:}

no. Human thyroid submaxillary gland and kidney; rat stomach; liver and kidney

\begin{tabular}{llllll}
\hline$M A^{*}$ & SMA & NA & $\begin{array}{l}\text { Thyro- } \\
\text { globulin }\end{array}$ & $\begin{array}{l}\text { Thyro- } \\
\text { microsomal }\end{array}$ \\
\hline 1 & - & 10 & - & - & - \\
2 & - & 10 & 10 & - & - \\
3 & $0-10$ & 10 & 40 & - & - \\
4 & $0-1$ & - & 10 & - & - \\
5 & 10 & 10 & 10 & 40 & - \\
6 & $40-160$ & - & - & - & $1280^{2}$ \\
7 & $40-160$ & - & 10 & - & - \\
8 & $10-20$ & - & 10 & - & - \\
9 & $40-80$ & 10 & 40 & - & \\
\hline
\end{tabular}

* Results on retesting at the Royal Free Hospital and Middlesex Hospital.

MA: mitochondrial antibody. SMA: smooth muscle antibody. NA: nuclear antibody.

also found to be positive at the Middlesex Hospital. The titres found were similar in all the patients except in patients 6 and 7, in whom mitochondrial antibody was found to be positive in a titre on 40 at the Royal Free Hospital, whereas at the Middlesex Hospital it was found to be 160 . Patients 3 and 4 who remained negative at the Royal Free Hospital were found to be positive in a very low titre-10 and undiluted serum respectively-at the Middlesex Hospital. There was no difference in the titres obtained when rat and human substrates were used. Two patients (patients 1-2) remained mitochondrial antibody negative on retesting in both laboratories.

Smooth muscle and nuclear antibodies were present mostly in low titres. Thyroid autoantibodies were found only occasionally. Patient 5 had thyroglobulin antibodies and patient 7 had thyroid microsomal antibodies both in high titres (Table 1).

Table 2 Main features found in two female patients who remained negative for mitochondrial antibody on retesting

\begin{tabular}{|c|c|c|}
\hline & Patient 1 & Patient 2 \\
\hline Age (yr) & 56 & 34 \\
\hline History (yr) & 2 & 3 \\
\hline Symptoms and signs at presentation & Itching, RUQ pain, weight loss & $\begin{array}{l}\text { Itching, jaundice, hepatosplenomegaly, } \\
\text { spider naevi }\end{array}$ \\
\hline Pi phenotype & MM & MS \\
\hline \multirow[t]{3}{*}{ Other autoimmune disease } & Sicca syndrome & Dermatomyositis \\
\hline & RTA & RTA \\
\hline & & Diabetes mellitus \\
\hline Total bilirubin $(5-17 \mu \mathrm{mol} / 1(0 \cdot 8-1 \cdot 2 \mathrm{mg} \%))$ & $18(1 \cdot 3)$ & $15(1 \cdot 1)$ \\
\hline SGOT (4-15 IU) & 52 & 109 \\
\hline Alkaline phosphatase (3-13 KAU) & 164 & 119 \\
\hline Alpha 1 antitrypsin $(>1.9 \mathrm{~g} / 1(>190 \mathrm{mg} \%))$ & $2 \cdot 4(240)$ & $1.7(166)$ \\
\hline $\operatorname{IgM}(0 \cdot 7-2 \cdot 8 \mathrm{~g} / 1(70-280 \mathrm{mg} \%))$ & $1 \cdot 1(105)$ & $1 \cdot 0(102)$ \\
\hline $\operatorname{IgG}(8-18 \mathrm{~g} / 1(800-1800 \mathrm{mg} \%))$ & $12.6(1260)$ & $10 \cdot 8(1080)$ \\
\hline $\operatorname{IgA}(0 \cdot 9-4 \cdot 5 \mathrm{~g} / 1(90-450 \mathrm{mg} \%))$ & $3 \cdot 2(320)$ & $1 \cdot 7(170)$ \\
\hline \multicolumn{3}{|l|}{ Liver biopsy } \\
\hline Latest stage of PBC seen & 3 & 3 \\
\hline Copper and CAP* staining & $++1++$ & $++1+t$ \\
\hline PAS-diastase resistant globules & Negative & Negative \\
\hline Immunoperoxidase for alpha 1 antitrypsin & Negative & Inconclusive \\
\hline
\end{tabular}

- Copper associated protein. 
The nine patients who were initially negative for mitochondrial antibody had a clinical history, LFTs, and histological changes suggestive of primary biliary cirrhosis when first presenting to medical care. They were all females and the mean age was 48 years ( 34 to 70 years). IgM was raised in five patients. Patient 4 had low serum levels of alpha 1 antitrypsin $(0.9 \mathrm{~g} / \mathrm{l}(92 \mathrm{mg} \%)$ normal, $1.9 \mathrm{~g} / \mathrm{l}(190 \mathrm{mg} \%))$. Liver biopsy of this patient showed some PAS-diastase resistant globules in hepatocytes. It was not possible to make additional studies as there was no follow-up in this patient. Extrahepatic bile ducts were shown to be clear in all the patients.

The liver biopsies of the nine patients were randomised and reviewed by a single observer. A total of 16 liver biopsies were reviewed. There was no marked differences between the patients who remained negative for serum mitochondrial antibody and the patients who were found to be positive for this antibody on retesting. All the patients had stage 3 or 4 of primary biliary cirrhosis. ${ }^{9}$

Two patients remained negative for serum mitochondrial antibody (patients 1-2) (Table 2). One patient, in spite of normal levels of IgM, had clinical, biochemical, and histological data suggestive of primary biliary cirrhosis. Her liver biopsy is shown in Fig. 1. She had Sicca syndrome at the time of presentation and two years later developed renal tubular acidosis. This patient was treated with D-penicillamine which over 16 months produced a fall in liver copper from $683 \mu \mathrm{m} / \mathrm{g}$ to $77 \mu \mathrm{m} / \mathrm{g}$ dry liver.

Patient 2 developed itching during pregnancy. After delivery she developed jaundice and hepatosplenomegaly. She was first seen at the Royal Free
Hospital three years later. She had itching, jaundi ce hepatosplenomegaly, and spider naevi (Table 2 ) SGOT and alkaline phosphatase were raised. Immunoglobulins were normal and a mild decrease in serum alpha 1 antitrypsin was noted $1.7 \mathrm{~g} / 1$ (166 $\mathrm{mg} \%$ ). Renal tubular acidosis was also diagnosed and one year later she developed dermatomyositis. She was then treated with prednisolone and later cyclophosphamide but showed no improvement. She developed complete heart block, right pleural effusion, and pulmonary consolidation. One year later she was diagnosed as having diabetes mellitus. Three liver biopsies were done and in all the histology was compatible with late PBC. No cholestasis was seen. Copper and copper-associated protein were found to be mildly increased by rhodanine and orcein staining respectively. ${ }^{10}$ Pas-diastase resistant globules were absent and immunoperoxidase examimation for alpha 1 antitrypsin was inconclusive (Table 2). The phenotype by acid starch gel electrophoresis was MS.

\section{MITOCHONDRIAL ANTIBODY POSITIVE \\ SUBJECTS WITH NORMAL SERUM}

ALKALINE Phosphatase (Table 3)

Patient $A$ was the daughter of a known patient with primary biliary cirrhosis. She requested medical examination and on questioning admitted mild premenstrual pruritus. She had normal liver function tests and IgM. She had a positive mitochondrial antibody. The liver biopsy revealed classical early primary biliary cirrhosis with granulomatous destruction of the biliary epithelium (Fig. 2).

Patient B presented with Hashimoto's thyroiditis in 1959. She had one sister with Hashimoto's
Fig. 1 Patient 1. Liver biopsy from mitochondrial antibody negative patient. Piecemeal necrosis (arrow) is seen at the edge of an expanded, inflammed portal tract. $H$ and $E, \times 136$.

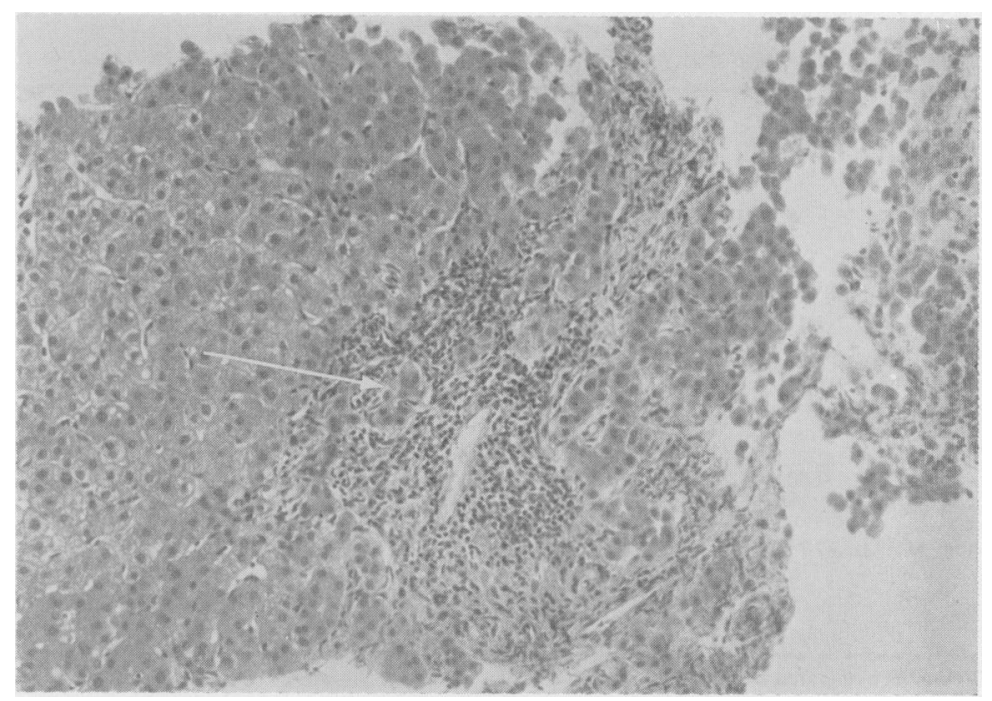


Table 3 Biochemical and serological data on mitochondrial antibody positive subjects with normal serum alkaline phosphatase

\begin{tabular}{|c|c|c|c|}
\hline & Patient $A$ & Patient B & Patient C \\
\hline Age (yr) & 41 & 55 & 53 \\
\hline Sex & Female & Female & Female \\
\hline Presentation & Itching & Hashimoto's disease & Food allergy \\
\hline Hepatomegaly & - & - & $-\div$ \\
\hline SGOT (4-15 IU) & 3 & 17 & 14 \\
\hline Alkaline phosphatase (3-13 KAU) & 5 & 6 & 11 \\
\hline $\operatorname{IgM}(0 \cdot 7-2 \cdot 8 \mathrm{~g} / 1(70-280 \mathrm{mg} \%))$ & $2 \cdot 3(228)$ & $2 \cdot 5(249)$ & $2 \cdot 3(228)$ \\
\hline $\operatorname{IgG}(8-18 \mathrm{~g} / \mathrm{l}(800-1800 \mathrm{mg} \%)$ & $10 \cdot 3(1030)$ & $14 \cdot 1(1410)$ & $11 \cdot 2(1120)$ \\
\hline $\operatorname{IgA}(10 \cdot 9-4.5 \mathrm{~g} / 1(10-450 \mathrm{mg} \%))$ & $1.6(160)$ & $1 \cdot 1(105)$ & $2 \cdot 5(250)$ \\
\hline Mitochondrial antibody & $40-160$ & $160-1000$ & 10 \\
\hline Smooth muscle antibody & Negative & Negative & Negative \\
\hline Nuclear antibody & Negative & Negative & Negative \\
\hline Liver biopsy (stage of PBC) & 1 & 1 & 1 \\
\hline
\end{tabular}

disease, one brother with type I diabetes mellitus, and one daughter with Graves' disease. She was noted to be mitochondrial antibody positive in 1962. She has remained asymptomatic with normal alkaline phosphatase and IgM until the present time. Liver biopsy, however, showed classical early primary biliary cirrhosis.

Patient $\mathrm{C}$ presented with food allergy and was noted to have hepatomegaly, a positive mitochondrial antibody, normal liver function tests, and IgM and liver biopsy again revealed early primary biliary cirrhosis.

\section{Discussion}

The incidence of 'mitochondrial antibody negative' primary biliary cirrhosis in a series of 218 cases was
$4 \%$ on initial screening. However, on retesting additional specimens and using undiluted serum, only two patients remained negative for this antibody.

Four of the seven patients who, on retesting, were found to be positive for the antibody had low titres at the limit of the sensitivity of the test. Differences in results obtained between the two laboratories emphasise the subjectivity of the immunofluoresence test system, particularly with low titre specimens. It is noteworthy that patient 4 had a positive mitochondrial antibody at the Middlesex Hospital only in undiluted serum. However, the incidence of false positive results must be determined before we can be sure that testing undiluted serum is generally useful. There were three patients (patient $6,7,9$ ) who were found to have high mitochondrial antibody titre on

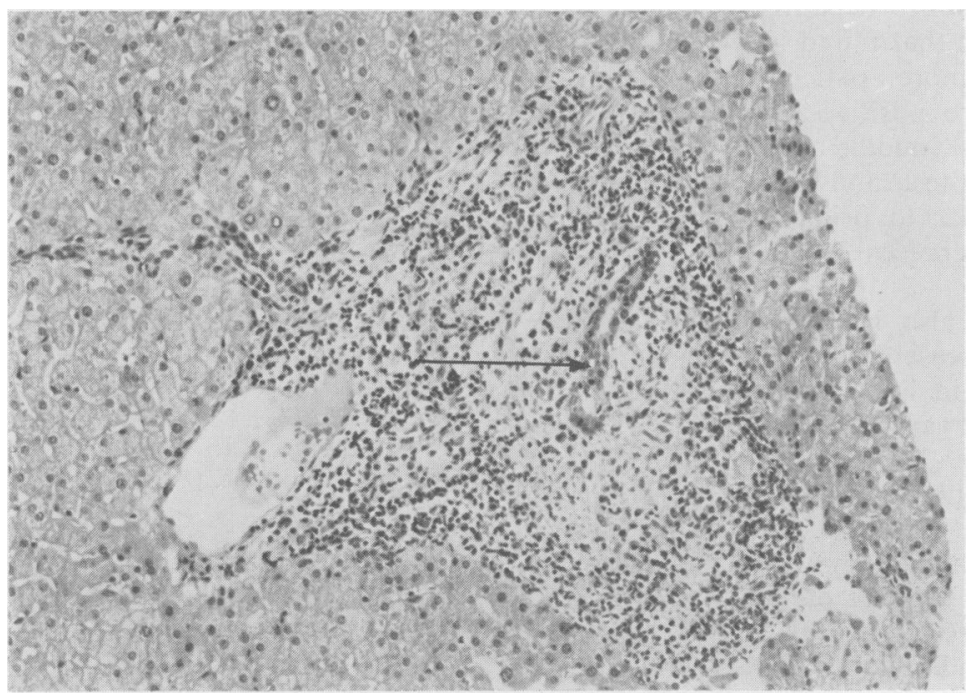

Fig. 2 Patient A. Liver biopsy from mitochondrial antibody positive patient with normal LFT's. Damaged bile auct (arrow) surrounded by a pale-staining zone of histocytes and darker lymphocytes and plasma cells. Haematoxylin and eosin. $H$ and $E, \times 136$. 
retesting in both laboratories. As the original specimen was not available for retesting, it remains possible that the discrepancy is related to human error. Alternatively, the patient may have developed the antibody in the intervening period (12-60 months). There was no difference in efficiency of detecting mitochondrial antibody when human and rat substrate were used.

Two patients remained negative for mitochondrial antibody on retesting in both laboratories. Patient 1 had clinical and biochemical data suggestive of primary biliary cirrhosis but hepatic histology was compatible and not diagnostic. Furthermore, the serum IgM level was always normal. Thus, although this patient had suggestive features of primary biliary cirrhosis, no definite conclusion could be reached. It is possible that the liver disease is of a different aetiology. In patient 2 the diagnosis of primary biliary cirrhosis must also remain in doubt. She had a clinical history, biochemistry, and hepatic histology suggestive but not diagnostic of the disease. She also had normal serum levels of IgM and, in addition, an alpha 1 antitrypsin heterozygous deficiency state.

This study suggests that 'mitochondrial antibody negative' primary biliary cirrhosis either has an extremely low incidence or it does not exist. Before making this diagnosis the mitochondrial antibody should probably be sought on several occasions in undiluted sera if necessary. In addition, other causes of intrahepatic cholestasis such as alpha 1 antitrypsin deficiency or sclerosing cholangitis must be considered.

Mitochondrial antibody has been detected in conditions other than $\mathrm{PBC}$ such as chronic active hepatitis and cryptogenic cirrhosis. ${ }^{3}$ However, the mitochondrial antibody in chronic active hepatitis may be of a different specificity from that found in primary biliary cirrhosis. ${ }^{11}$ Furthermore, patients with cryptogenic cirrhosis who were positive for mitochondrial antibody test were middle-aged women with cholestatic liver function tests and liver biopsies appearance somewhat similar to primary biliary cirrhosis. ${ }^{35}$ Thus these may represent a late stage of primary biliary cirrhosis.

The mitochondrial antibody has also been reported in patients with collagen disease ${ }^{1213}$ : these patients also showed abnormalities in liver histology, ${ }^{12}$ some of which might represent early primary biliary cirrhosis. Positive results have also been reported in normal subjects who did not have biopsies but have shown absence of symptoms. ${ }^{14}$ In this study similar subjects who had normal alkaline phosphatase and IgM have been shown to have early primary biliary cirrhosis. We, therefore, suggest that in many instances where the mitochondrial antibody was said to be associated with conditions other than primary biliary cirrhosis, the diagnosis of primary biliary cirrhosis had not been adequately excluded. Even in asymptomatic subjects with normal liver function tests, the presence of the mitochondrial antibody may indicate the presence of intrahepatic lesions of primary biliary cirrhosis. These data strongly suggest that, if the mitochondrial antibody is positive, the diagnosis is likely to be primary biliary cirrhosis.

We wish to thank Dr P J L Cook for determining the protease inhibitor phenotype. HCT is a Wellcome Senior Research Fellow.

\section{References}

${ }^{1}$ Walker JG, Doniach D, Roitt IM, Sherlock S. Serological tests in diagnosis of primary biliary cirrhosis. Lancet 1965; i: 827-31.

${ }^{2}$ Goudie RB, MacSween NM, Goldberg: Serological and histological diagnosis of primary biliary cirrhosis. $J$ Clin Pathol 1966; 19: 527-38.

${ }^{3}$ Doniach D, Roitt IM, Walker JG, Sherlock S. Tissue antibodies in primary biliary cirrhosis, chronic active hepatitis, cryptogenic cirrhosis and other liver diseases and their clinical implications. Clin Exp Immunol 1966 1: 237-62.

${ }^{4}$ Doniach D, Walker JG, Roitt IM. 'Autoallergic' hepatitis. $N$ Engl J Med 1970; 282: 86-8.

${ }^{5}$ Klatskin G, Kantor FS. Mitochondrial antibody in primary biliary cirrhosis and other diseases. Ann Intern Med 1972; 77 : 533-41.

${ }^{6}$ Sherlock S, Scheuer PJ. The presentation and diagnosis of 100 patients with primary biliary cirrhosis. $N$ Engl $J$ Med 1973; 289: 674-8.

${ }^{7}$ Fox RA, Scheuer PJ, Sherlock S. Asymptomatic primary biliary cirrhosis. Gut 1973; 14: 444-7.

${ }^{8}$ Long RG, Scheuer PJ, Sherlock S. Presentation and course of asymptomatic primary biliary cirrhosis. Gastroenterology 1977; 72: 1204-7.

${ }^{9}$ Scheuer PJ. Primary biliary cirrhosis. Proc $R$ Soc Med 1967; 60: 1257-60.

${ }^{10}$ Jain S, Scheuer PJ, Archer Barbara Newman SP, Sherlock S. Histological demonstration of copper and copper-associated protein in chronic liver disease. J Clin Pathol 1978; 31 : 784-90.

${ }^{11}$ Klöppel G, Selfert G, Lindner H, Dammermann R., Sack HJ, Berg PA. Histopathological features in mixed types of chronic aggressive hepatitis and primary biliary cirrhosis. Virchows Arch [Pathol Anat] 1977; 373: $143-60$.

${ }^{12}$ Walker JG, Doniach D, Doniach I. Mitochondrial antibodies and sub-clinical liver disease. $Q J$ Med 1970; 153: 31-48.

${ }^{13}$ Whaley K, Goudie RB, Williamson J, Nuki G, Dick WG, Buchanan WW. Liver disease in Sjögren syndrome and rheumatoid arthritis. Lancet 1970; i: 861-3.

${ }^{14}$ Doniach D. Autoimmunity in liver disease. Prog Clin Immunol 1972; 1: 45-70. 